\title{
A comparative evaluation of post placental intrauterine contraceptive device (IUCD) insertion between normal delivery and caesarean section
}

\author{
Sharmistha Sarkar*, Dhruba Prasad Paul, Jayanta Ray
}

Department of Obstetrics and Gynecology, Agartala Government Medical College and GBP Hospital, Agartala, Tripura, India

Received: 14 June 2018

Revised: 29 July 2018

Accepted: 02 August 2018

\section{*Correspondence:}

Dr. Sharmistha Sarkar,

E-mail: drsharmistha01@gmail.com

Copyright: (c) the author(s), publisher and licensee Medip Academy. This is an open-access article distributed under the terms of the Creative Commons Attribution Non-Commercial License, which permits unrestricted non-commercial use, distribution, and reproduction in any medium, provided the original work is properly cited.

\begin{abstract}
Background: Adverse maternal and perinatal outcomes are related to pregnancies spaced too closely together. Objective of present study was to compare the expulsion rate and complications between post placental IUCD insertion between caesarean section and vaginal delivery.

Methods: This study was a prospective comparative study conducted in the department of Obstetrics and Gynecology, at Agartala Government Medical College over 1.5 Years (January 2016-June2017) All cases at term pregnancy delivering by caesarean section and vaginal delivery were divided into two different groups. Sample size of 105 in each group. Subjects recruited from-obstetrics OPD and casualty of Agartala Government Medical College (AGMC) and GB Pant Hospital expulsion rate and complications. Comparative evaluation of Expulsion rate and complications following post placental IUCD insertion between caesarean section and vaginal delivery at the end of six months, one year and one and half year.

Results: There was no significant difference in either complications between the two groups (P value-.913) or outcomes (p value-.035). Expulsion rate $18.2 \%$ following vaginal delivery compared to those with intracaesarean insertion i.e $3.8 \%$.

Conclusions: The complications associated with postplacental Intrauterine device insertion is insignificant, still the awareness, acceptance and continuation are very low. Therefore Information, education Communication activity by the field workers must be enhanced to overcome this knowledge gap.
\end{abstract}

Keywords: Intrauterine device, Intracaesarean insertion, Post placental contraception

\section{INTRODUCTION}

Adverse maternal and perinatal outcomes are related to pregnancies spaced too closely together. Closely spaced pregnancies is associated with an increased risk of induced abortion, miscarriage, neonatal death, premature birth, placental abruption, low birth weight, congenital disorders, schizophrenia and autism.

Pregnancy interval of five years or more is associated with an increased risk of high blood pressure and signs of damage to another organ system, often the kidneys. ${ }^{1}$ Family planning during the first year postpartum has the potential to reduce a significant proportion of these unintended pregnancies as women experience a large UNMET NEED for family planning during this time. ${ }^{2}$

PPIUCD is employed in this study as a definitive method of post-partum contraceptive device as

- It is safe to use as it is certain that the woman is not pregnant at the time of insertion, 
- There is minimal risk of perforation because of thick wall of uterus, there is reduced perception of initial side effects (bleeding and cramping).

- No effect on breastfeeding and Inserting IUCD in the immediate post partum period saves time for both the woman and the provider as the procedure is conducted in the same setting and involves only a few minutes of additional time. ${ }^{3}$

This study has been done to compare the complications of post placental IUCD insertion between caesarean section and vaginal delivery among women delivering in Agartala Government Medical College and at the same time benefit the female population of the state with long acting reversible contraception.

Objective of present study was to compare the expulsion rate and complications between post placental IUCD insertion between caesarean section and vaginal delivery.

\section{METHODS}

This study was a prospective comparative study conducted in the department of Obstetrics and Gynaecology, at Agartala Government Medical College over 1.5 Years (January 2016-June2017). All cases at term pregnancy delivering by caesarean section and vaginal delivery were divided into two different groups. Sample size of 105 in each group. Subjects recruited from- Obstetrics OPD and Casualty of Agartala Government Medical College and GB Pant Hospital.

\section{Exclusion criteria}

- $\quad$ Patient with $\mathrm{He}<8 \mathrm{gm} \%$,

- Ruptured membranes $>18$ hours prior to delivery,

- Chorioamnitis,

- $\mathrm{PPH}$.

All registered women were first counseled during antenatal period, consent taken and PPIUCD inserted within 10 minutes of expulsion of placenta and membranes thereafter study subjects were asked to follow up at six months, one year and one and half year to evaluate the differences in expulsion rate and complications.

Statistical analysis testing was conducted with SPSS 15.0 and Microsoft Excel software.

\section{RESULTS}

In this study, stipulated sample size was 105 subjects for both vaginal delivery and caesarean section, but only 55 women gave consent for insertion of postplacental IUCD insertion in vaginal delivery group, rest of the couples refused inspite of proper counselling (Table 1).
Table 1: Selection of study subjects.

\begin{tabular}{|lll|}
\hline Total counselled $(\mathrm{N})$ & 13 & $\begin{array}{l}\text { Vaginal } \\
\text { delivery }\end{array}$ \\
\hline Total accepted $(\mathrm{N})$ & 105 & $>200$ \\
\hline
\end{tabular}

Table 2 shows distribution of sociodemographic factors among women accepting PPIUCD, $75.2 \%$ in Caesarean Section group and $81.8 \%$ in the vaginal delivery group are in the age group of 21-30 years.

In both the groups $>70 \%$ of women were primiparous, $>88 \%$ of women were Hindu, followed by Christan $6.3 \%$ and Muslim 5.8\%. Educational qualification of almost $50 \%$ study subjects were upto Secondary Stage, followed by Senior Secondary $>$ Middle Stage $>$ Primary Stage $>$ No Formal education $>$ Undergraduate. $54.3 \%$ and $41.8 \%$ of study subjects belonged to upper lower socioeconomic strata while $1 \%$ and $0 \%$ belonged to upper socioeconomic strata in intracaesarean and vaginal delivery groups respectively.

Table 3 shows no significant difference in complications between the two groups at sixth month, one year and one and half year ( $\mathrm{p}$ value $>0.01$ ).

Between the two groups, at the end of Sixth month most common complication was pain abdomen (4.8\%) in caesarean section and expulsion $(9.1 \%)$ in vaginal delivery group, at the end of one year bleeding was the most common complication in both caesarean section $(3.8 \%)$ and vaginal delivery $(5.5 \%)$, at the end of one and half year expulsion was seen in $9 \%$ cases in vaginal delivery group.

The most common complication at the end of One and Half year is expulsion ( 7 cases), followed by infection ( 3 cases), pregnancy (2 cases), bleeding and pain abdomen (1 case each). 61 cases either lost to follow up or had Copper T (CuT) removed.

Table 4 shows awareness about PPIUCD is very low (70\%) among the women of delivering in AGMC. 35\% in Caesarean Section and $20 \%$ in vaginal delivery group.

Table 5 shows differences in outcomes between the two groups, $48.75 \%$ were satisfied with its use, $12(7.5 \%)$ cases had it removed for bleeding, 6 cases $(3.8 \%)$ had it removed for pelvic infection, $1(.6 \%)$ had it removed for pressure from family, $1(.6 \%)$ had it removed for string problems, $5(3.1 \%)$ had it removed for vaginal discharge and purities vulvae, $2(1.3 \%)$ had it removed as husband or child expired, $2(1.3 \%)$ conceived with Copper $\mathrm{T}$ in situ, in $14(8.8 \%)$ cases it got expelled spontaneously. 35 $(21.3 \%)$ cases lost to follow up. Difference in outcomes between the two groups is statistically insignificant ( $p$ value 0.035$)$. 
Table 2: Sociodemographic factors distribution among the study subjects.

\begin{tabular}{|c|c|c|c|c|c|c|}
\hline & CS & CS & VD & VD & Total & Total \\
\hline & $\mathbf{N}$ & $\%$ & $\mathbf{N}$ & $\%$ & $\mathbf{N}$ & $\%$ \\
\hline \multicolumn{7}{|l|}{ Age } \\
\hline$<20$ & 12 & 11.40 & 5 & 9.10 & 17 & 10.60 \\
\hline $21-25$ & 52 & 49.5 & 30 & 54.50 & 82 & 51.30 \\
\hline $26-30$ & 27 & 25.70 & 15 & 27.30 & 42 & 26.30 \\
\hline $31-35$ & 10 & 9.50 & 5 & 9.10 & 15 & 9.40 \\
\hline$>35$ & 4 & 3.80 & 0 & 0 & 4 & 2.50 \\
\hline \multicolumn{7}{|l|}{ Parity } \\
\hline 1 & 87 & 82.90 & 38 & 70.40 & 125 & 78.60 \\
\hline 2 & 15 & 14.30 & 12 & 22.2 & 27 & 17 \\
\hline$>2$ & 3 & 2.9 & 4 & 7.40 & 7 & 4.4 \\
\hline \multicolumn{7}{|l|}{ Religion } \\
\hline Hindu & 92 & 87.60 & 49 & 89.10 & 141 & 88.1 \\
\hline Muslim & 4 & 3.80 & 5 & 9.10 & 9 & 5.6 \\
\hline Christain & 9 & 8.60 & 1 & 1.80 & 10 & 6.30 \\
\hline \multicolumn{7}{|l|}{ Education } \\
\hline No formal education & 11 & 10.50 & 2 & 3.60 & 13 & 8.10 \\
\hline Primary stage & 13 & 12.40 & 2 & 3.60 & 15 & 9.40 \\
\hline Middle stage & 14 & 13.30 & 6 & 10.90 & 20 & 12.50 \\
\hline Secondary stage & 47 & 41.80 & 32 & 58.20 & 79 & 49.40 \\
\hline Senior secondary stage & 15 & 14.30 & 12 & 21.80 & 27 & 16.90 \\
\hline Undergraduate & 5 & 4.8 & 1 & 1.80 & 6 & 3.80 \\
\hline \multicolumn{7}{|l|}{ Occupation } \\
\hline Housewife & 91 & 86.70 & 48 & 87.30 & 139 & 86.90 \\
\hline Employed & 14 & 13.30 & 7 & 12.70 & 21 & 13.10 \\
\hline \multicolumn{7}{|l|}{ Socioeconomic strata } \\
\hline Upper & 1 & 1 & 0 & 0 & 1 & 0.60 \\
\hline Upper middle & 0 & 0 & 1 & 1.80 & 1 & 0.60 \\
\hline Lower middle & 14 & 13.30 & 28 & 50.90 & 42 & 26.30 \\
\hline Upper lower & 57 & 54.30 & 23 & 41.80 & 80 & 50 \\
\hline Lower & 33 & 31.40 & 3 & 5.50 & 36 & 22.50 \\
\hline
\end{tabular}

Table 3: Comparison of Complications at $6^{\text {th }}$ month, $12^{\text {th }}$ month and $18^{\text {th }}$ month.

\begin{tabular}{|c|c|c|c|c|c|c|c|c|c|c|c|c|}
\hline & \multicolumn{4}{|c|}{ At $6^{\text {th }}$ month } & \multicolumn{4}{|c|}{ At $12^{\text {th }}$ month } & \multicolumn{4}{|c|}{ At $18^{\text {th }}$ month } \\
\hline & CS & VD & CS & VD & CS & VD & CS & VD & CS & VD & CS & VD \\
\hline & $\mathbf{N}$ & $\%$ & $\mathbf{N}$ & $\%$ & $\mathbf{N}$ & $\%$ & $\mathbf{N}$ & $\%$ & $\mathbf{N}$ & $\%$ & $\mathbf{N}$ & $\%$ \\
\hline Pain Abdomen & 5 & 4.8 & 1 & 1.8 & 3 & 1 & 0 & 0 & 1 & 1 & 0 & 0 \\
\hline Bleeding & 3 & 2.9 & 2 & 3.6 & 4 & 3.8 & 3 & 5.5 & 1 & 1 & 0 & 0 \\
\hline Expulsion & 2 & 1.9 & 5 & 9.1 & 0 & 0 & 1 & 0 & 2 & 1.9 & 5 & 9.1 \\
\hline Pregnancy & 0 & 0 & 0 & 0 & 0 & 0 & 0 & 0 & 2 & 1.9 & 0 & 0 \\
\hline Infection & 0 & 0 & 0 & 0 & 0 & 0 & 1 & 1.8 & 2 & 1.9 & 1 & 1.8 \\
\hline No complications & 80 & 76.20 & 39 & 70.90 & 69 & 65.70 & 33 & 60 & 58 & 55.2 & 28 & 50. \\
\hline \multirow[t]{2}{*}{ Lost to follow up } & 15 & 14.30 & 8 & 14.50 & 29 & 27.60 & 17 & 30.9 & 37 & 35.2 & 24 & 43.6 \\
\hline & \multicolumn{4}{|c|}{$\mathrm{p}$ value 0.284} & \multicolumn{4}{|c|}{$\mathrm{p}$ value 0.284} & \multicolumn{4}{|c|}{$\mathrm{p}$ value 0.913} \\
\hline
\end{tabular}

Table 4: Awareness about PPIUCD between the study subjects.

\begin{tabular}{|lllll|}
\hline Awareness & & Caesarean section & Vaginal delivery & Total \\
\hline \multirow{2}{*}{ Aware } & $\mathrm{N}$ & 37 & 11 & 48 \\
& $\%$ & 35.2 & 20.0 & 30.0 \\
\hline \multirow{2}{*}{ Not aware } & $\mathrm{N}$ & 68 & 44 & 112 \\
\multirow{2}{*}{ Total } & $\%$ & 64.8 & 80.0 & 70.0 \\
\hline & $\mathrm{N}$ & 105 & 55 & 160 \\
\hline
\end{tabular}


Table 5: Comparison of outcomes of PPIUCD insertion after caesarean section and vaginal delivery.

\begin{tabular}{|c|c|c|c|c|}
\hline Outcomes & & $\begin{array}{l}\text { Caesarean } \\
\text { section }\end{array}$ & $\begin{array}{l}\text { Vaginal } \\
\text { delivery }\end{array}$ & Total \\
\hline \multirow{2}{*}{ Satisfied } & $\mathrm{N}$ & 56 & 22 & 78 \\
\hline & $\%$ & 53.3 & 40 & 48.8 \\
\hline \multirow{2}{*}{$\begin{array}{l}\text { Removed for } \\
\text { bleeding }\end{array}$} & $\mathrm{N}$ & 8 & 4 & 12 \\
\hline & $\%$ & 7.6 & 7.3 & 7.5 \\
\hline \multirow{2}{*}{$\begin{array}{l}\text { Removed for } \\
\text { pelvic pain }\end{array}$} & $\mathrm{N}$ & 5 & 1 & 6 \\
\hline & $\%$ & 4.8 & 1.8 & 3.8 \\
\hline \multirow{2}{*}{$\begin{array}{l}\text { Removed for } \\
\text { pressure from } \\
\text { family }\end{array}$} & $\mathrm{N}$ & 1 & 0 & 1 \\
\hline & $\%$ & 1.0 & 0.0 & 0.6 \\
\hline \multirow{2}{*}{$\begin{array}{l}\text { Removed for } \\
\text { string } \\
\text { problems }\end{array}$} & $\mathrm{N}$ & 0 & 1 & 1 \\
\hline & $\%$ & 0.0 & 1.8 & 0.6 \\
\hline \multirow{2}{*}{$\begin{array}{l}\text { Removed for } \\
\text { vaginal } \\
\text { discharge and } \\
\text { pruritis }\end{array}$} & $\mathrm{N}$ & 1 & 4 & 5 \\
\hline & $\%$ & 1.0 & 7.3 & 3.1 \\
\hline \multirow{2}{*}{$\begin{array}{l}\text { Removed for } \\
\text { pelvic } \\
\text { infection }\end{array}$} & $\mathrm{N}$ & 2 & 2 & 4 \\
\hline & $\%$ & 1.9 & 3.6 & 2.5 \\
\hline \multirow{4}{*}{$\begin{array}{l}\text { Removed for } \\
\text { failure of } \\
\text { contraception } \\
\text { Removed as } \\
\text { husband/child } \\
\text { expired }\end{array}$} & $\mathrm{N}$ & 2 & 0 & 2 \\
\hline & $\%$ & 1.9 & 0 & 1.3 \\
\hline & $\mathrm{N}$ & 0 & 2 & 2 \\
\hline & $\%$ & 0.0 & 3.6 & 1.3 \\
\hline \multirow{2}{*}{$\begin{array}{l}\text { Expelled } \\
\text { spontaneously }\end{array}$} & $\mathrm{N}$ & 6 & 8 & 14 \\
\hline & $\%$ & 5.7 & 14.5 & 8.8 \\
\hline \multirow{2}{*}{$\begin{array}{l}\text { Not } \\
\text { known/lost to } \\
\text { follow up }\end{array}$} & $\mathrm{N}$ & 24 & 11 & 35 \\
\hline & $\%$ & 22.9 & 20.0 & 21.3 \\
\hline \multirow{2}{*}{ Total } & $\mathrm{N}$ & 105 & 55 & 160 \\
\hline & $\%$ & 100.0 & 100.0 & 100.0 \\
\hline
\end{tabular}

Table 6: Comparison of continuation of PPIUCD between the two groups.

\begin{tabular}{|c|c|c|c|c|}
\hline & & $\begin{array}{l}\text { Caesarean } \\
\text { section }\end{array}$ & $\begin{array}{l}\text { Vaginal } \\
\text { delivery }\end{array}$ & Total \\
\hline \multirow[t]{2}{*}{$\begin{array}{l}\text { Removal at } 6 \\
\text { months }\end{array}$} & $\mathrm{N}$ & 7 & 3 & 10 \\
\hline & $\%$ & 7.00 & 6.40 & 6.80 \\
\hline \multirow[t]{2}{*}{$\begin{array}{l}\text { Removal at } \\
\text { one year }\end{array}$} & $\mathrm{N}$ & 9 & 6 & 15 \\
\hline & $\%$ & 9.00 & 12.80 & 10.20 \\
\hline \multirow[t]{2}{*}{$\begin{array}{l}\text { Removal at } \\
\text { one and half } \\
\text { year }\end{array}$} & $\mathrm{N}$ & 8 & 7 & 15 \\
\hline & $\%$ & 8 & 14.90 & 10.20 \\
\hline \multirow[t]{2}{*}{ Continued } & $\mathrm{N}$ & 53 & 20 & 73 \\
\hline & $\%$ & 53 & 42.60 & 49.70 \\
\hline \multirow[t]{2}{*}{$\begin{array}{l}\text { Lost to } \\
\text { follow up }\end{array}$} & $\mathrm{N}$ & 23 & 11 & 34 \\
\hline & $\%$ & 23.00 & 23.40 & 23.10 \\
\hline
\end{tabular}

Table 6 shows $53 \%$ continued in caesarean section group and $42.6 \%$ continued copper $\mathrm{T}$ in vaginal delivery group ( $\mathrm{p}$ value 0.677 ).

\section{DISCUSSION}

Women soon after delivery are highly motivated and intend for an effective contraception method while if the women are advised to initiate contraception after 6 weeks of their delivery, they may have higher chances of conception and do not manage to come back.

In this study, majority $(51.3 \%)$ of woman accepting PPIUCD belonged to age group of 26-30 years, which is similar to study conducted by Sujanendra et al and Katheit $\mathrm{G}$ et al, furthermore amongst women accepting PPIUCD, $78.6 \%$ were primiparous, this finding is consistant with study conducted by Sujanendra et al, but contrary to these studies Grimes et al, Sukla et al, and Deshpande et al where they found higher acceptance in multiparous client. ${ }^{4-8}$ The reason for lower acceptance for PPIUCD in our study among para 2 or more was that they underwent BTL. In this study, acceptance of PPIUCD was higher among women with secondary stage education and senior secondary stage education i.e. $49 \%$ and $12.5 \%$ respectively than those with no formal or higher education i.e. $8.1 \%$ and $3.1 \%$, similar to study conducted by Sujanendra et al and $50 \%$ of present study subjects belonged to Upper Lower Socioeconomic strata. ${ }^{4}$

In this study, follow up visits were conducted at $6^{\text {th }}$ month, $12^{\text {th }}$ month and $18^{\text {th }}$ month and complications noted in both the groups (105 subjects in Caesarean Section and 55 subjects in Vaginal delivery group. Pain was reported as 5\%, 3\% and $1 \%$ for Intracaesarean PPIUCD and $1 \%, 0 \%, 0 \%$ for post-placental PPIUCD at the end of 6 month, 12 months and 18 months respectively. Total $5.7 \%$ i.e. 9 cases ( 8 cases in intracaesarean and 1 case after vaginal delivery) had pain Abdomen, the difference in pain between the two groups was not statistically significant. Out of which 6 cases insisted removal, rest 3 cases continued with it and pain subsided with intake of Analgesics. Similar to study performed by Katheit $\mathrm{G}$ et al where minor abdominal pain consisted of $12.5 \%$ of all complications. Follow up at 6 months, 1 years and one and half year $3(2.9 \%), 4$ (3.8\%), 1 (1\%) cases of bleeding per vagina following Intracaesarean PPIUCD and $2(3.6 \%), 3(5.5 \%)$ and 0 cases following vaginal delivery. ${ }^{5}$ So, at the end of One and Half year 13 cases $(16.8 \%)$ of bleeding Per vagina (7.7\% following intracaesarean and $9.1 \%$ following vaginal delivery) were recorded, the difference noticed between the two is not statistically significant. Of the 13 cases, all of them were prescribed with combination of tranexamic acid and mefenamic acid thrice daily for 5 days but 12 of them had it removed from other private centers. In other studies, $23.5 \%$ and $17.79 \%$ of clients had bleeding. Infection rate being $0,0,2$ cases after intracaesarean PPIUCD and $0,1,0$ cases after postplacental insertion follow up at 6 months, 1 year and 
one and half year, there is no difference between the two groups. $^{9}$ Infection was on basis of abdominal pain associated with fever and foul-smelling vaginal discharge. Similar to study conducted by Ranjana et al, in my study, 2 cases i.e. 1 intrauterine and 1 extrauterine pregnancy with IUCD in situ was reported after one and half year following caesarean section. ${ }^{10}$ The case reporting with intrauterine pregnancy at 16 weeks of gestation termination of pregnancy was done with Copper $\mathrm{T}$ removal, and Laparotomy followed by salpingectomy with Copper $\mathrm{T}$ removal was done with the one with tubal pregnancy. Present study shows expulsion rate as 2 $(1.9 \%), 0,2(1.9 \%)$ and $5(9.1 \%), 0,5(9.1 \%)$ at $6^{\text {th }}, 12^{\text {th }}$, $18^{\text {th }}$ month following intracaesarean and vaginal insertion of IUCD respectively. In this study there is higher rate of expulsion i.e. $18.2 \%$ following vaginal delivery compared to those with intracaesarean insertion i.e. 3.8\%, probably because the post placental insertion of IUCD was conducted by the post graduate trainees and intracaesarean insertion was conducted by consultants. In my study Expulsion was detected by history, clinical examination and pelvic ultrasonography. These women were informed about IUCD expulsion and were advised to use alternative method of contraception. According to Chi et al, expulsion rate of PPIUCD at 4 weeks interval was $9.5-12.5 \% .{ }^{11}$ In this study, $8(7.6 \%)$ removed for bleeding, $5(4.8 \%)$ removed for pelvic pain, 1 (1.0\%) removed for pressure from family, 0 removed for string problems, $1(1 \%)$ removed for vaginal discharge and pruritis, 2 (1.9\%) removed for pelvic infection, 2 (1.9\%) removed for pregnancy with IUCD inn situ, 0 removed as husband or child expired, in $6(5.7 \%)$ cases it got expelled spontaneously following Caesarean section . Continuation rate is $57 \%$ following Caesarean section and $47 \%$ following vaginal insertion of PPIUCD. In contrast to other studies where continuation rate ranges from $82-62 \%$, the continuation rate in my study is very low. ${ }^{10,11}$

\section{CONCLUSION}

The complications associated with Postpartum Intrauterine Contraceptive Device is insignificant, still the awareness, acceptance and continuation are very low. Therefore, the Information Education Communication activity by the field workers must be enhanced to overcome this knowledge gap, in the long run this will improve the acceptance of Contraceptives especially the IUCDs in the general population.

\section{ACKNOWLEDGMENTS}

Authors would like to thank Dr. Jayanta Ray, Dr. Dhruba P. Paul, Dr. Mamata Pradhan, who has been a continuous support and constant supervision.

Funding: No funding sources
Conflict of interest: None declared

Ethical approval: The study was approved by the Institutional Ethics Committee

\section{REFERENCES}

1. Post-Partum IUCD reference manual. New Delhi Family Planning Division, Ministry of Health and family Welfare, Government of India; 2010. Available at http://www.nrhmtn.gov.in/modules/PPIUCD\%20Refere nce\%20Manual.pdf

2. IUCD reference Manual for Medical Officers, Family Planning Division, Ministry of Health and family weldfare, Govt of India;2010:1-20 Available at https://nrhm.gujarat.gov.in/images/pdf/IUCD_Referenc e_Manual_Nursing_Personnel.pdf

3. Konar H. DC Dutta"s Textbook of Gynaecology. $7^{\text {th }}$ Ed. Jaypee;2016:92-7.

4. Mishra S. Evaluation of safety, efficacy and expulsion of postplacental and intracaesarean insertion of intrauterine contraceptive devices. J Obstet Gynaecol India. 2014;64(5):337-43.

5. Katheit G, Agarwal J. Evaluation of Post-placental Intrauterine Device in terms of awareness, acceptance and expulsions in tertiary care hospital. Int $\mathrm{J}$ Reprod Contracept Gynaecol. 2013 Dec;2(4):539-43.

6. Grimes DA, Lopez LM, Schulz KF, Van Vleit HA, Stanwood NL. Immmediate post-partum insertion of intrauterine devices. Cochrane Database Syst Rev. 2010;15:CD003066.

7. Sukla M, Sabuhi Qureshi C. Post-placental intrauterine device insertion: a five year experience at a tertiary care centre in north India. Indian $\mathbf{J}$ Med Res.2012;136(3):432.

8. Deshpande S, Gadappa S, Yelikar K, Wanjare N, Andurkar S. Awareness, Acceptability and clinical outcome of post-placental insertion of intrauterine contraceptive device in Marathwada region, India. Ind J Obstet Gynaecol Res. 2017;4(1):77-82.

9. Ranjana Verma A, Chawla I. A follow up study of postpartum intrauterine device insertion in a tertiary health centre. Int J Reprod Contracept Obstet Gynaecol. 2017;6:2800-5.

10. Chi IC, Wilkens L, Roger S. Expulsions in immediate postpartum insertion of Lippes Loop D and Copper T IUD's and their counterpart Delta devices-an epidemiological analysis. Contraception. 1985;32:11934.

11. Mohamed SA, Kamel MA, Shaaban OM, Salem HT. Acceptability for the use of postpartum intrauterine contraceptive devices: Assiut experience. Med Princ Pract. 2003;12:170-5.

Cite this article as: Sarkar S, Paul DP, Ray J. A comparative evaluation of post placental intrauterine contraceptive device (IUCD) insertion between normal delivery and caesarean section. Int J Reprod Contracept Obstet Gynecol 2018;7:3826-30. 